the whole land that after the a'foresaid archbishop has excommunicated them and they have remained under the sentence for forty days our lord the king may take their temporalities into his hand until they are willing to obey and to observe and keep the aforesaid sentence, and that half the issues of the temporalities remain as alms to our lord the king, and the other half, if it please him, be allowed (? in relief of) the pledge of the sum which they will give to have the common law. And they ask our lord the king that the justiciar of Ireland appoint a keeper on behalf of our lord the king, and the archbishop of Cashel another by the counsel of prelates, who will work loyally with him to save the same goods that they be not embezzled nor turned to evil use.

Moreover the said archbishop and his two brother bishops who are with him loyally promise that they will exert loyal power that all the other archbishops and bishops of Ireland may hold the same sentences in their provinces and bishoprics by the aid and council of our lord the king. And if they will not hold them the aforesaid prelates promise in good faith that by the aid and counsel of our lord the king they will obtain at their expense from the pope, as much as in them is or can be, that he by distress of holy church make the aforesaid sentences to be held until those who are (? outside the) law will hold it. And if our lord the king and his council see that they can apply other counsel to uphold the aforesaid law they are ready to do so, that Almighty God may know they say this without dissimulation of heart or mind, that their will is that loyalty peace and truth should be in the land, and therefore they wili excommunicate all those of whatever nation they be who disturb the peace of our lord the king and the aforesaid law, and they will obtain confirmation of this from the pope.

\title{
VII. Sharman Crawford on The RePeal QUestion, I847
}

THE writer of the following letter, William Sharman Crawford, had been led from a policy of unionısm to acquiescence in O'Connell's repeal policy soon after the first agitation of it in 1830 . He subsequently abandoned repeal for the less comprehensive home-government scheme of federalismthe establishment in Dublin of a local government and legislature, subordinate to the imperial parliament, to administer purely Irish concerns. At this time (1847), he was again turning towards repeal as the best solution of the problem of satisfactorily governing Ireland. His letter was elicited by the announcement that William Smith O'Brien intended heading a 
deputation of Young Irelanders to Belfast with a view to enlisting northern recruits for the Irish Confederation.

The document, which is marked 'private', is contained in the Smith O'Brien Papers in the National Library of Ireland.

\section{BRIAN A. KENNEDY}

[N.L.I., MS 439, no. 1984.]

Crawfordsburn, Holywood

Sept. 8, 47

My dr S. O’Brien

Some time back I think I saw a notice in some one of your speeches of an intention to visit Belfast on a public mission. Now I am anxious to say that if you should come there I should have great pleasure in seeing you at Crawfordsburn and receiving you as a friend to whom I am very sincerely attached-no matter whether we could come to a perfect agreement on political questions or not. At the same time I believe the shades of differences are not very remote.

It is quite evident that the repeal question is greatly rising in importance. You know my adhesion has long been given to the principle of a domestic legislature. But I never was able to see my way to get rid of the difficulties which must arise from an independent parliament possessing all the power of the constitution of 1782 . On various occasions, and in various letters, I put these difficulties to O'Congêll, but he never answered them-or removed them. It was for this reason I advocated the federal principle, although I admit objections would arise to constituting an imperial parliament for the United Kingdom of this nature. If the federal principle be not adopted, I do not see that you could have a separate parliament in Ireland except it be on the colonial principle, of which the constitution of the Canada parliament affords a favourable example. I mentioned this matter in some letters I wrote a few years back, when the federal principle was raised, and O'Connell gave a half consent to entertain it. But then this proposition was instantly cried down on the ground that it was treating Ireland not as a nation but a colony Nationality was the watch word and I believe still is so, with the party of the Nation paper. It is a fine sounding word, but how it was possible to obtain that real nationality without a totally distinct government as well as legislature I never could understand. I do not think it is possible. I am taking the liberty of mentioning this matter to you because if you come to Belfast you should be prepared on them [sic] Observe, Belfast is prosperous and you need not expect that they have sufficient patriotism to induce them to do anything for the rest of Ireland unless they were convinced that it would not stop the progress of their own prosperity-or in truth unless they were convinced that it might promote it. They are all freetraders in principle. They must be satisfied that the free commercial relations with Great Britain would nc: be disturbed. Then how can this be secured in the case of 
two independent parliaments? No one need attempt to argue the subject with hope of success in Belfast, unless that question can be answered. You will observe that there are practical men. There a person arguing for the repeal of the union, must show practically, not theoretically, what would be the measures of a local parliament, which would be advantageous and which could not be obtained from an imperial parliament. The corruption by which the union was carried and the unjustness of the financial arrangements (although admitted) would not have the least weight in Belfast. They would consider all that a matter past and gone. The question would be: what shall be the new order of things, and how under that change is our prosperity to be insured or increased? You will understand, in these points I am throwing out, I am not endeavouring to throw objections or impediments in your way. Quite the reverse : I have a strong feeling in favour of the principle and I am anxious to have my own objections removed. I do not mean $m y$ objections alone, but the objections of a large body of the most intelligent of this part of Ireland who think with me, and I think it only fair to you that if you come to Belfast you should be prepared on these particular subjects which I refer to.

Another matter is-I am of opinion that the repeal question suffered immensely by not being discussed in parliament. $\mathrm{O}^{\prime} \mathrm{C}$. only brought it in once several years back, but the question of the details of a measure was not then raised nor ever has been raised in parliament. If a measure be a good measure every discussion in parliament, no matter how small the divisions, will increase the chance of success. It looks like want of confidence in the justness of a cause, when the supporters of it have not the moral courage to raise it in the legislature. There never has been any great question carried which has not been debated again and again in parliament for long periods with the most unfavourable results. If the objections I now raise can be answered, that ought to be done in parliament, and if effectively answered there, how great would be the impression on the public mind of England as well as Ireland. You know it never will be carried (unless by force of arms) except the judgment of the people of England be acted on and this can only be done by discussion in parliament. I think the present time is peculiarly favourable for that purpose. I think it would not be hard to show to the people of England that some arrangement for putting Ireland, to a certain extent, on her own resources would be very desirable for England.

Another subject occurs to me-I observe a meeting of Irish members is contemplated before the parliamentary session. I think this would be highly useful if any thing like a unity of sentiment could be obtained and publicity allowed to their proceedings-not as last year in walls closed against reporters. This however is a matter I can have no personal interest in, as I conclude the meeting as now proposed would be limited to members representing places in Ireland. I think however there is nothing could tend more to advance the question of repeal than a well conducted, temperate, manly demonstration from Irish members suggesting good and useful measures to the legislature. If they should 
do so and then measures be neglected by the imperial parliament, a strong argument would become named in favour of the repeal question. I have no doubt that bitter debates will occur next session of parliament on the rating question. I am certain that in many parts of Ireland (although not in this), it will be impossible to pay all the rates which must be imposed to discharge the advances made on the different acts. The English members will contend against any aid from the public funds for the payment of these rates, and they will object to any more money being granted for Irish purposes or improvements. I think the result will be some kind of national income tax must be imposed on Ireland if only for her own uses, which would be applied under certain rules in aid of local wants and local taxation. Mr Godley proposed something of this kind for imigration purposes. Now if any species of national tax be imposed for the uses of Ireland, the necessary consequence would be a demand for a local national representation body to direct its application, and thus the foundation of a local legislature would be laid. It appears to me that in discussing the question of ' repeal', the great and essential point as to the practical part of the subject will be the financial arrangement. It would be necessary to show that Ireland can at least bear her own expenses. How is this to be effected-by what system of taxation is it to be done? Then is she to be liable for any portion of the national debt? Can it be shown that England will be relieved from expense in any way by the arrangement which would be proposed? Depend upon it, whenever the question is raised in parliament, the points I have last referred to must be answered and explained. There are so many who look to pounds, shillings, and pence on these matters, rather than to the more patriotic point of national independence. The opinions of the great majority both in the north of Ireland and in England will be formed pro or con according to the result to be expected on the financial and commercial relations which will be created by the change.

When I began this letter I had no conception it would be spun out to such length. However I think it will not be unacceptable to you to find that I take an interest in this great question. You will consider it however altogether private and confidential. I should wish to know about what time you propose being in this county, as I have an intention of being absent from home for a little time to visit my son in the south at his official station in Cork and its neighbourhood.

Believe me, dr S. O'Brien

Yrs very sincerely

W. S. O’Brien, Esq., M.P

Wm Sharman Crawford 